Article

\title{
Eco-Initiatives in Municipal Cultural Institutions as Examples of Activities for Sustainable Development: A Case Study of Poznan
}

\author{
Mateusz Rozmiarek $^{1, *(\mathbb{D})}$, Kevin Nowacki ${ }^{2}$ (D) Ewa Malchrowicz-Mośko $^{1}$ (D) and Zdzisława Dacko-Pikiewicz ${ }^{3} \mathbb{( D}$ \\ 1 Department of Sports Tourism, Faculty of Physical Culture Sciences, Poznan University of Physical Education, \\ 61-871 Poznan, Poland; malchrowicz@awf.poznan.pl \\ 2 Faculty of Political Sciences and Journalism, Adam Mickiewicz University in Poznan, 61-614 Poznan, Poland; \\ kevin.nowacki@interia.pl \\ 3 Department of Management, Faculty of Applied Sciences, WSB University, 41-300 Dabrowa Gornicza, Poland; \\ zdacko@wsb.edu.pl \\ * Correspondence: rozmiarek@awf.poznan.pl
}

check for updates

Citation: Rozmiarek, M.; Nowacki,

K.; Malchrowicz-Mośko, E.;

Dacko-Pikiewicz, Z. Eco-Initiatives in

Municipal Cultural Institutions as

Examples of Activities for

Sustainable Development: A Case

Study of Poznan. Sustainability 2022,

14, 682. https://doi.org/10.3390/

su14020682

Academic Editor: Søren Askegaard

Received: 3 December 2021

Accepted: 4 January 2022

Published: 8 January 2022

Publisher's Note: MDPI stays neutral with regard to jurisdictional claims in published maps and institutional affiliations.

Copyright: () 2022 by the authors Licensee MDPI, Basel, Switzerland. This article is an open access article distributed under the terms and conditions of the Creative Commons Attribution (CC BY) license (https:/ / creativecommons.org/licenses/by/ $4.0 /)$.

\begin{abstract}
The aim of the study is to demonstrate which pro-environmental initiatives consistent with the idea of sustainable development are undertaken by municipal cultural institutions in Poznan-the largest city in the Greater Poland region in Poland. The diagnostic survey was conducted by means of interviews with directors of municipal cultural institutions or their representatives. A total of 12 (out of 15) municipal cultural institutions from the city of Poznan were surveyed. All were asked to cite specific examples of their activities, visualising their institution's approach to ecology. The results indicated that the institutions undertake numerous eco-initiatives, which very often fit into the discourse on so-called "deep ecology" and address the sources of the existing environmental crisis. Their activities are also aimed at stimulating a "return to nature" of the city's inhabitants. In addition to initiatives aimed at the recipients of the offer of individual institutions, many institutions also pay attention to pro-environmental internal activities. In effect, the results could be divided into three general groups, which include internal institutional activities, the implementation of projects on environmental themes, and educational activities in the field of ecology. However, these activities were undertaken individually, as the survey revealed a lack of inter-institutional cooperation on ongoing projects.
\end{abstract}

Keywords: eco-initiatives; culture; cultural institutions; cultural events; cultural services; sustainable development; environment; ecological education; Poznan; Poland

\section{Introduction}

Civilizational transformation and climate change are increasingly affecting the cultural sphere $[1,2]$. In the face of the dynamic changes taking place and the crisis of traditional cultures, it has therefore become extremely important for cultural managers to take diverse measures aimed at promoting sustainable and responsible attitudes among recipients of the cultural offer-attitudes that will respond to the threats posed by climate change [3,4]. Their legitimacy is confirmed, among others, by Agenda 21—the first global document addressing the issue of sustainable cultural governance, developed in 2008 (and updated in subsequent years) by the Committee on Culture within United Cities and Local Governments, which is a global network of United Nations cities, local governments, and municipal associations [5]. Creating the right conditions for multi-faceted sustainable development is a necessary action for undertaking bottom-up initiatives (including eco-initiatives) aiming to change the current reality. Although these actions are not the simplest, they require fast implementation (they are very important and urgent), as they may ultimately enrich the culture not only of a given community, but also of each particular person. 
As the third decade of the 21st century begins, sustainable development is increasingly being promoted by European cities through their cultural institutions, including through environmental activities [6-11]. This is a response to the growing problems of humanity [12-14]. One of such cities is Poznan (Polish spelling: Poznań), a city in Poland with a population of almost half a million. According to the Act of 25 October 1991 on organizing and conducting cultural activity, in the Republic of Poland [15], a cultural institution is a unit of the public finance sector established to carry out public tasks in the area of cultural activity, consisting in the creation, dissemination, and protection of culture. Its primary objective, both for state and local government units, is to conduct cultural activity that does not constitute economic activity within the meaning of separate regulations [16,17]. However, cultural institutions may engage in economic activities, including in the form of separate economic activities (e.g., trading or service activities). While the economic activities of an institution should be motivated solely by the opportunity to make a profit in order to develop its core statutory activities, rather than replacing them with profit-making activities; in line with the concept of sustainable cultural management, profit-making should be put in the background and focus should be placed on the need to finance culture in order to maximize its impact [18].

In Polish cultural entities, growing emphasis is being placed on the issues of greening the cultural offer and sustainable management in the cultural sphere. Poland is thus moving in the direction of changing the perception of culture and giving it a much greater role in development processes, taking into account the context of sustainability. Indeed, the theory of sustainable development has become a fundamental strategy for guiding the socio-economic transformation of many countries in the world [19]. Global sustainability experts, in recent years, have developed the concept of "cultural sustainability", which links cultural beliefs and practices and the protection of heritage with sustainable development, placing culture as a driver of the social, economic, and environmental dimensions of sustainability [20]. The role of culture has been emphasized, among others, in the concept of "Circles of Sustainability" - a method of understanding and assessing sustainable development and managing projects focused on socially sustainable results [21]. Due to the extremely important role of culture in sustainable development, its old model, based on the three pillars of social, economic, and ecological, had to be updated with culture as a category of growing importance, which, through its influence, creates good practices and influences the change of society's approach to sustainability [22]. Such an inclusion has been proposed, for example, by Pasqual [23], in his concept of the square of sustainable development; but in order to adapt his model to the issue related to the management of institutions, it seems a better solution would be to propose the square-circle concept, visualized in Figure 1.

Among the six key points needed to contribute to the achievement of the Sustainable Development Goals in a feasible manner, as outlined in the report "Transformations to Achieve the Sustainable Development Goals" produced by the world in the 2050 initiative and presented at the United Nations High Level Political Forum in New York, are increased education for better environmental choices, responsible consumption and production, water conservation, and energy saving [24]. The emphasis on these issues in the field of broadly understood culture should come as no surprise, as sustainable development in the context of ecology or environmental protection also appears in other areas of life, such as tourism [25,26] or sport [27-29], which can be linked to lifestyle [30], or activities reflecting the socio-cultural context [31]. At the same time, it should be remembered that the activities undertaken by cultural institutions affect not only the direct recipients of their offer, as they also cause an increase in the ecological sensitivity of the individual in a much wider audience (e.g., family, friends, and acquaintances of the recipients of the cultural offer). The holistic treatment of institutions as a complex of units located within a particular territory (state, voivodeship, poviat, commune, or city), which engage in sustainable development by supporting and facilitating new sustainable undertakings, allows for defining them as actors of the Entrepreneurial Ecosystem (EE), according to the general definition of the term, 
which was quoted by Boyd Cohen [32]. According to this researcher, the purpose of EE is to create benefits (e.g., improved environmental conditions, increased social awareness, improved health, or economic growth) by developing new sustainable businesses in the process of creating social, environmental, and economic value [32]. The mechanisms that are characterized in addressing EE have been known for several decades. Initially, researchers focused only on individual cases of business entities, without considering other public or private entities that generated specific benefits for the local or regional environment through a set of interdependent components [33]. Olav R. Spilling noted that there are many different links between entities that develop due to environmental factors and interactions. He referred to the development of enterprises, infrastructure, or public institutions [34]. These individuals undertake so-called entrepreneurial events, which are characterized by taking the initiative, consolidating resources, managing the organization, relative autonomy, and taking risks [35]. Research has shown that individual system actors can have different impacts on the overall development of a region [36]. Neck and colleagues undertook research to identify the components of EE in Boulder, Colorado, relating to a cluster of technology start-ups. Among the components, they listed formal and informal networks, physical infrastructure, and social culture [37]. Networks are understood as a set of links (individuals, organizations, and institutions) connected by a set of social relations of a specific type [38]. Physical infrastructure includes the tangible infrastructure components of an area, for example roads, offices, or real estate used by the units in the network. Social culture, on the other hand, is supposed to make a given unit, organization, or institution unique, due to its location, intellectual capital, or ability to implement advanced modern technologies [39].

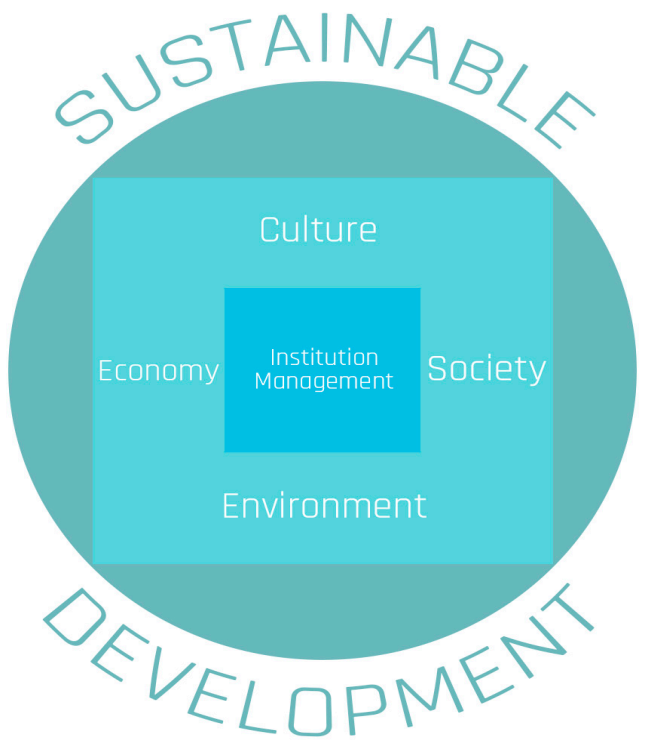

Figure 1. Adaptation of the sustainable development model in institution management. Source: Own work.

All of the above components can also be applied to cultural institutions. The services provided by them allow for various socio-economic benefits to be achieved, which are important from the point of view of the development of cities and regions. They can build social capital, increase the attractiveness of cities, improve the quality of urban life, or support social policy [40]. Markiel notes that there is a lack of a broad view of the various functions of culture in contemporary civilization, and that the perspective of creation ahead of change, a license for economic development, a foundation for social education, the labor market, and a tool for social policy should be analyzed [41]. Jach recognizes the need for cultural institutions to address ecological issues, speaking of "multi-level actions for a more sustainable use of resources. The material is important, as are the relationships between 
staff, long-term program planning, and the involvement of the local community" [42]. A great advantage of cultural institutions is their central location, often in attractive, historic buildings, as well as having educated staff who can act as leaders and animators of the local community. Very often, in order to fulfil new functions, it is necessary to introduce various changes in activities, both in the organization of the space and in the attitude of the staff, so as to go beyond their traditional, existing functions [43].

The functioning of an institution depends on many factors. These include, for example, the location that may be of interest to the public, the size of the institution, the number of staff, the question of resource intensity, or even the amount of annual subsidy related to the financing of the units [44]. If they are at a high level compared to other cultural institutions, the cultural institution should be able to carry out pro-environmental activities in a much more simple and accessible way. The type of activities undertaken also depends on them-whether a given unit undertakes only managerial and institutional activities in the field of ecology, or also programmatic activities, including initiatives aimed directly at the recipients of the cultural offer. The former essentially depends only on the good will and individual approach of the institution's management, as there are no statutory guidelines for implementing specific solutions. The most common initiatives include the segregation of waste and abandoning the purchase of plastic water bottles and promoting drinking tap water. This is followed by the introduction of electronic document circulation, limiting the printing of promotional materials or printing in the form of brochures or leaflets on ecological paper, saving electricity, and using reusable accessories [42]. The implementation of these projects is often an impulse to go wider and start pro-environmental activities not only directed inside, but also, and above all, outside the institution.

The article will present eco-initiatives undertaken by municipal cultural institutions from Poznan-a city located in the central-western part of Poland (in the Greater Poland region), which, in 2016, competed for the title of the European Capital of Culture [45]. In order to verify possible differences in the approach of individual institutions, the year 2019 - the year before the outbreak of the COVID-19 pandemic - and the pandemic year 2020 were indicated as the time caesura of initiatives in the surveyed entities. All municipal cultural institutions (15 entities) were invited to the survey in order to present the broadest possible spectrum of initiatives, while at the same time indicating recurring activities. The variety of institutional models and ways of working presented by the selected examples made it possible to capture not only significant similarities, but also equally significant differences in the ways in which the actions taken were implemented.

\section{Materials and Methods}

Numerous cultural institutions, both state and local government, flourish in Poznan. There are several theatres in the city, including the city-managed Polish Theatre, Musical Theatre, Animation Theatre, and the offshoot Theatre of the Eighth Day. Museums and art galleries play an important role in the cultural map of the city. Particularly noteworthy among the museums is the Greater Poland Museum of Independence, which has six branches; the Museum of Archaeology; and the Arsenal Municipal Gallery located on the Old Market Square. Choral music is represented by Poznan Boys' Choir, and the Raczyński Library is responsible for reading, with 39 branches across the city. An essential role in the promotion of culture is also played by Zamek Culture Centre-one of the largest cultural institutions in the country, organizing annually about 2500 events in such fields as theatre, film, music, and literature. In Poznan, Estrada Poznańska, Posnania Municipal Publishing House, "Daisy" House of Culture, Children's Art Centre, and Poznan Heritage Centre also undertake their activities.

Because Hawkes [46] defined culture as the fourth and most important pillar of sustainable development, which was confirmed by UNESCO placing it at the centre of sustainable development policy [47], the aim of the study was to demonstrate which pro-environmental initiatives consistent with the idea of sustainable development are undertaken by municipal cultural institutions in Poznan. A diagnostic study to establish the 
factual situation using the interview research method was conducted using the technique of individual semi-structured interviews focused on the problem with directors of municipal cultural institutions or their representatives. Thanks to the method and technique used [48], it was possible to obtain information about the problem under study without forcing statements, which justified its usefulness for this study. The study was treated according to the guidelines in the Publication Manual of the American Psychological Association [49]. The survey was voluntary; therefore, a total of 12 (out of 15) representatives of municipal cultural institutions were interviewed. The remaining three did not respond to the request for answers. The research was conducted during the COVID-19 pandemic and due to the difficulty of conducting face-to-face meetings, the process of getting answers to the interviews was done remotely via email or phone calls. All responses were collected and written down and then analyzed. In January 2021, the authorities of the institutions were sent a written request to answer the main question: "What eco-initiatives have been undertaken in the institution in the last two years (i.e., 2019 and 2020) internally and during the cultural events organised in order to promote environmental attitudes among the participants of the events?". Those interested in the study were contacted and asked to respond. In the case of laconic or non-exhaustive answers, the main question was supplemented with supporting questions: "Does the institution pay attention to ecology?". How does the institution approach the subject of ecology?" "Are there any environmental activities accompanying the institution when it organises events for residents?". Everyone was asked to cite specific examples of activities visualising the institution's approach to ecology. The adoption of such methodological assumptions, known, among other things, from research into the problems of sustainable tourism management of sporting events in protected areas [50], gave a guarantee of the reliability and comprehensiveness of the conducted research.

\section{Results}

\subsection{Institution 1}

The director of the institution indicated that the pro-ecological initiative in which the institution managed by him (as the only one from Poland) took part, was the international project "\#Resolution2020". It was a musical protest against the human degradation of the natural environment. The project's patrons included Keira Knightley, Emma Thompson, and Annie Lennox. The project brought together artists and activists from all over the world who shared a common goal- to raise public awareness of the problem of climate change. Each participant recorded their own version of the song "World On Your Shoulders" by Robin Howl, Violet Skies, and Holly Fletcher. According to the data obtained, more than 100 countries joined the action. The video of the project was shot in Poznan. The colourful sculptures visible in the video, among which the choristers are standing, are "Totems"an artistic installation that is a symbol illustrating the scale of destruction of the natural environment in the world. Each of the six totems dealt with a different issue, such as smog, deforestation, or the extinction of wild animal populations. The initiative was noticed by the local and national media. The institution appealed to the public to let its project inspire concrete steps to reduce the impact of environmental problems. Although the effect of the appeal is immeasurable, it reached a wide audience, as the show has been viewed by nearly 15,000 people on YouTube alone.

\subsection{Institution 2}

The director of the institution indicated that the activities of the unit always involve respect for people and nature. The institution's activities include, among other things, collecting, storing, conserving, researching, and making collections on historical and social topics available. Because of the cultivation of the past, it is impossible not to think about the future. When organising museum events during the two years in question, out of generally understood pro-ecological principles, the institution saved paper by sending electronic invitations to events and preparing press materials in electronic form. When 
planning refreshments for vernissages or meetings in a wider group, it organised them without the use of plastic utensils, and when handing out gadgets or exhibition catalogues, it only used paper bags. The unit also tried to ensure that its events, stagings, and demonstrations generated a minimum amount of waste. The institution thus operated on the economic (e.g., reducing the purchase of pa-pieces), environmental (e.g., recycling), and social (e.g., learning good practices) pillars of sustainability, holistically embedding its activities in the cultural sector.

\subsection{Institution 3}

The institution undertakes internal pro-environmental activities, producing numerous gadgets from ecological materials and printing information materials on recycled paper. In addition, in the 2018 /2019 season, the unit produced the premiere of a contemporary play with an environmental theme, aimed at young audiences. The play was a contemporary variation on a nineteenth century novel of children's literature. The protagonists fight for a sense of meaning and agency, but they know that in this age of absurdity and ecological catastrophes, it may be a losing battle. Looking through their eyes at the nonsense and cruelty of modern times, the audience could see the transformations that have taken place in the world in the last 100 years. The play's premiere was accompanied by a workshop for teachers (with a special focus on teachers of grades 6-8), which was part of an educational package. The name of the workshop, which with the institution was organised by the Teacher Training Centre in Poznan, was "WR100 Global about us-consumerism and climate change, what can we do about it?". In 2020, due to the pandemic, the institution was forced to develop new forms of maintaining contact with the audience and fulfilling the statutory objectives of a cultural institution, which is why the performance was recorded and is available on the unit's website via a VOD platform. It is estimated that the performance reached several thousand young viewers, who, in the future may, thanks to it, take a different look at the ecological challenges of today's world.

\subsection{Institution 4}

The institution tries to take up pro-environmental issues and testify to its attitude, e.g., by choosing environmentally friendly solutions during the renovation and modernisation of its premises. Examples of such actions include restoring old armchairs instead of replacing them with new ones, and using old advertising banners to sew commemorative gadgets out of them. The institution pays great attention to the strict segregation of waste, requiring this also from the audience and all partners cooperating with the theatre. The institution's popular water dispensers with plastic bottles have been abandoned, replaced by a tap water filtering machine located in an accessible place. Care was taken to ensure that the system for washing and cleaning items (used by the institution and its guests) was environmentally friendly, and a decision was made to use an energy-efficient dishwasher and washer dryer. The use of paper was also kept to a minimum, with an emphasis on communicating and promoting on the internet. The director reported that the unit now produces only the necessary number of placards (currently 4; when the institution opened there were 20) and programme leaflets (when the institution opened there were 250). The lighting in the institution has been replaced by energy-efficient LED bulbs, and when producing new shows, the staff are guided by the idea of creating them in such a way as to make use of the resources already available. The winners of the competitions organised by the institution, as well as young art students working together on the production of performances, are also taught how to construct scenery in such a way that it is created economically and, above all, can be used again and again, also in other projects. In 2019, a performance was organised, with the theme of one of the elements being a worryingly carefree approach to climate change. In 2020, the institution planned to start a series of meetings around ecology, and the first guest gave a lecture on the ecological disaster. The COVID-19 pandemic thwarted these plans, although two other events with pro-ecological themes were organised. The first was an online meeting with a journalist who talked about ecological disasters, and the second 
concerned cooperation on the play, dedicated to the youngest viewers, which talks about ecological changes. Thus, despite the problems resulting from the functioning of a cultural institution in the era of the COVID-19 pandemic, the institution has tried to continue its mission and carry out activities also on pro-ecological themes, although to a limited extent. The use of ecological solutions during the renovation of the premises before the pandemic and the restoration of furniture is something that significantly distinguishes the institution from the others. Such activities may be an example of good practices inspiring other entities towards similar activities.

\subsection{Institution 5}

The institution did not take up the issue and gave a laconic reply that it did not promote pro-environmental attitudes among the audience during its performances and other theatre-related events".

\subsection{Institution 6}

The institution is not an organiser of cultural events, as its activities are focused on other types of undertakings_-running a cultural information centre, publishing books, designing official city souvenirs, running an internet portal devoted to culture, or conducting occasional educational activities. As a result, the unit does not have many opportunities to undertake any forms of promoting pro-ecological attitudes. However, the permanent offer of souvenirs includes at least a dozen items of an ecological character (e.g., pens made of ecological paper, eco-notebooks, reusable cotton eco-bags, or reusable shopping bags). When organising educational workshops or other such meetings, the management relies on common sense and the conviction that adopting a pro-environmental attitude is the duty of every citizen, and in particular of the employees working for the local government. For this reason, reusable crockery is used at promotions and, where this is not possible, disposable paper crockery or ecological plastic is used. The institution also tries to use reusable utensils and ecological paper. The institution therefore carries out pro-environmental activities within the limits of its capabilities.

\subsection{Institution 7}

In the years covered by the survey, the institution took up ecological themes in various activities related to individual fields of art. The director mentioned, among others, the movie review section, in which each film was accompanied by educational materials or play packages about natural energy, zero waste, and being free of plastic bags. In a competition for plays for children and young people organised by the unit, a distinction is awarded to the drama with a theme related to the problem of climate change. Proenvironmental themes have also emerged during some of the creative meetings held as part of the workshops. All these projects have, as far as possible, reduced the use of artificial materials and kept plastics to a minimum, replacing them with natural materials such as paper, cardboard, cotton, poster paints, ecological acrylic paints, wooden slats, jute strings, cotton ropes, waste wood, sand, and various types of pebbles and stones. At the same time, a number of pro-environmental solutions have been adopted throughout the institution's activities, which are related to the events organised by the unit. These include reducing the use of plastic at all events (paper pens, paper cups, wooden cutlery, and Biennale fans with a wooden stick instead of a plastic one), and opting for ecological paper (notebooks, folders), as well as purchasing paper bags and sacks without labels so that they are universal and can be used for various projects. This has reduced the purchase of this type of packaging for specific events. The unit also uses stamps to associate them with a particular event, minimises the use of edition numbers on accompanying printed materials and gadgets so that they last longer than just one edition, and reduces print runs to only the necessary minimum. 


\subsection{Institution 8}

The issue of ecology is important for the institution. The institution tries to promote pro-environmental attitudes among its employees (electronic circulation of documents, from 2019 printing only on ecological paper) and comes out with many initiatives outside, aimed towards the audience. In producing its gadgets, it collaborates with local artists, which is also part of its environmental awareness. In March 2019, the institution announced the action following the idea of upcycling, and encouraged Poznan residents to spring clean their wardrobes and sew gadgets from the donated trousers. In 2020, a special project was entirely devoted to caring for the environment. The programme guideline for the edition was the idea of climate protection and raising awareness of the dangers of civilisation by introducing good practices into everyday life, including recycling, renovation, revitalisation, book-crossing, waste segregation, using renewable energy sources, and healthy living. These issues were addressed during thematic workshops, performances and concerts. An online ecological guide was also created during the edition. It contained practical knowledge on how we can contribute to change and how to start being eco-friendly. One of the activists coordinating the project explained issues such as the greenhouse effect or zero waste to the audience. The edition also resulted in the creation of a family board game made out of ecological materials, a variation on the well-known memory theme. The game is FSC-certified, which confirmed that raw materials were used in its production while preserving the vitality of forests and their biological wealth. One of the results of the other series organised by the institution was the publication of a children's booklet with rhymes, tasks, and illustrations, which was printed on certified ecological paper made from $100 \%$ recycled paper. Since the emergence of the COVID-19 pandemic, the institution has been recording podcasts as part of the green conversation series, in which it discusses, among other things, various forms of pro-environmental initiatives, mutual aid, and the fight against the exploitation of nature and man in various guises and scales. The institution has also included ecological elements in the programme of the international film festival. Due to the COVID-19 pandemic, the competition was held in a hybrid formula, and one of the online events was a student project, comprising short, several dozen-seconds etudes, presenting different ways of interpreting and reflecting on the issues of climate catastrophe and ecological threats. In turn, on the occasion of the other film festival taking place in September 2020, the institution conducted workshops on sewing multi-use pouches for loose produce, fruit, and vegetables. The repeated use of handmade shopping bags is part of the trend to abandon single-use plastic bags and is a grassroots social effort to minimise pollution in the world.

\subsection{Institution 9}

The main form of promoting pro-ecological attitudes in and through the institution is the popularisation of books connected with this subject matter and the promotion of certain actions (or active abstention in the right idea, e.g., abstaining from shopping). The institution communicates that using their sources is an expression of ecological attitudes in many respects, because thanks to it, consumption is reduced, available copies of books are used for multiple uses, and their recirculation is restored (in 2019 alone, Poznan residents donated nearly 15,000 copies of books and magazines to the institution, the unused copies of which would have resulted in their being thrown away). The institution also organised events that were entirely constructed to show and promote pro-ecological attitudes. The best example of these is a series of meetings for children and adults. In 2019, the vast majority of the meetings were dedicated to nature. Among the topics covered were forestry, gardening, herbalism, taking care of water purity together with its management, or animal protection. An ecological aspect was also present during the annual night project, and its events included, for example, a lecture on how nature affects people or how individual decisions concerning our environment can improve its condition. The finale of the edition was a fashion show prepared by students of the Fashion Department of the University of Arts in Poznan, and all the outfits presented on the catwalk were made from recycled 
materials. In September 2020, during one of the public events, the institution presented 120 seedlings of different raspberry varieties to the guests. A month later, it co-organised an exhibition of graphics, paintings, and drawings, during which foresters, in the course of curatorial tours, talked about how a forest is created, what plants and animals can be found in Polish forests, and how to protect the forests. In turn, in November 2020, four employees from the institution took part in the training course about ecoliterature, subsequently sharing the knowledge gained from the training with other colleagues of the unit.

\subsection{Institution 10}

The institution, in its pro-environmental activities, pays attention both to the building (which consumes energy and produces waste) and to the institution, which introduces and will continue to introduce ecological themes into its programme, and into the way it organises its events-principles resulting from environmental responsibility. In 2019, an environmental audit was carried out at the institution. The observation and interviews carried out in the first part of the research dealt with various aspects of daily functioning in the office and the implementation of programme projects. Among the topic areas were energy (including electrical equipment, lighting, and heating), food and water, paper, office supplies, waste, cleaning, and environmental education. The second part of the research looked at attitudes towards environmentally friendly practices in work, transport, and diet, and sought to capture whether there was potential to introduce and promote more environmentally and animal friendly practices in food and transport. The report also included an introductory section on key issues related to responsible consumption and carbon footprint reduction, as well as recommendations and guidance on how to make changes. The five-person team responsible for the implementation of pro-climate measures was established in January 2020. Its competencies included consulting on the organisation of work in the building and in office spaces, contacts with tenants and the preparation of recommendations for entities using the institution's space on a temporary or permanent basis, the preparation of a catalogue of good practices for event organisers, the organisation of training courses for employees, establishing cooperation with other institutions, the organisation of joint actions and events, and an attempt to create a "Culture for Climate" coalition. The team is also involved in implementing the recommendations of the environmental audit.

Among the systemic measures in the institution, the change in the development of the courtyard in front of the institution deserves special attention. Since April 2019, an architectural competition has been launched and work on the construction project has taken place. The institution plans to transform square, currently used as a car park, into a green courtyard, a place for meetings and inspiration and an element of a real revitalisation of downtown Poznan. In addition to its daily recreation function, the institution wants to use the square for its educational and animation program, as well as for small music and theatre events. From the very beginning, the ecological aspect has been central to the planned changes in the courtyard. With the transformation of this space, the greening of the inner city will increase, the possibility of retaining surface water and rainwater from the roofs will be created, the "heat is land" effect will be reduced, and the space will become inhabitable for insects. The targeted abandonment of car parking will also encourage people to choose alternative, more environmentally friendly modes of transport, facilitated by a new tram stop planned in front of the institution. Since 2017, the institution has been working with an electronic document circulation system. Thanks to this, paper consumption in the institution's offices has been steadily decreasing, and remote working during the COVID-19 pandemic has meant that paper consumption has decreased even further. Importantly, $75 \%$ of the institution's paper is ecological (unbleached and unchlorinated). In recent years, there has also been a reduction in the number of printed monthly programmes and occasional leaflets, as well as gadgets accompanying events. The institution has put an emphasis on recycled gadgets (bags for the festivals made of advertising banners and 
masks made of old tablecloths) or reusable gadgets (lanyards for badges). Even before the introduction of the pandemic, the management of the institution decided that on Mondays, the unit would not light up in the dark in order to demonstrate the need to save energy. However, in view of the epidemic and the depopulated city, it was decided that the nighttime illumination would not be switched on at all until further notice, which generated savings of $139 \mathrm{kWh}$ and about 36 PLN per day. The institution also conducted workshops for employees and tenants of the space in the series "How to properly segregate municipal waste". The workshops arose from the need to reduce the amount of rubbish thrown away and to resolve many doubts concerning its segregation in offices and common spaces (also in the context of changes in waste management). The institution is now planning to create a "warehouse of common items" for its internal use, in particular art and office supplies used for various organised events.

The institution has undertaken a number of events to promote ecological attitudes. As part of one of the series, a workshop on ornithology and a zero-waste training were organised. When organising one of the music festivals in 2019 and 2020, it organised a discussion panel for the exhibition and the screening of the documentary film about the environment topics. For many years, festival organisers have been combining joyful contact with music with the creation of ecological awareness among the festival's numerous audiences. Most of the performers who appeared in the last two years are artists for whom the relationship between man and nature is extremely important, which they reflect in their work or in arrangements of traditional music. Moreover, artists (especially from the world's music circle) are aware and sensitive to ecological issues (e.g., they include in their riders and contracts provisions concerning vegetarian meals, and requests not to use disposable plastic packaging or plastic water bottles), which also translates into organisational issues and the choices of the festival organisers. The institution, in a subsequent series of events, proposed that inhabitants take a look at contemporary ways of travelling and their effects, inviting participants to jointly seek alternatives to mass tourism and discover new forms of leisure compatible with the idea of sustainable development. The reads series included several meetings with authors of books devoted to such topics as ecology, food waste, nature and forest protection, and bird conservation. Six texts from the eco-critical guide for teachers and students for secondary schools were also published on the project website. In August 2020, a panel discussion and an art workshop for children combined with a plant presentation took place. A series of podcasts were produced about the phenomenon of urban gardening or reducing consumption in the context of the ecological crisis and environmental devastation.

The institution also undertakes its own online campaigns to promote environmental attitudes. On 22 September 2020, the International Car Free Day, it presented in social media its employees who reach the institution by public transport, bicycle, or on foot. In November, on the occasion of Black Friday, the institution's online media featured books presenting how our lives change (or can change) when we radically reduce our daily consumption and buy less.

\subsection{Institution 11}

The institution undertakes internal pro-environmental activities, producing numerous gadgets from ecological materials and printing information materials on recycled paper. The institution held 18 events dedicated to ecology in 2019 and 2020. In January 2019, there was a family workshop, a weaving workshop, and a workshop aimed at empowering and supporting people who engage in activism-including pro-environmental activism-on a daily basis. An initiative on what shape philosophy and ecology will take after the end of the world was a meeting dedicated to the Anthropocene and dark ecology. From June to September 2019, residents of Poznan could admire the installation placed in the Botanical Garden of Adam Mickiewicz University in Poznan and drawing attention to the environments of rubbish heaps or the vegetation of post-industrial areas. Further ecoworkshops were organised in the autumn. In the winter holidays of 2020, the institution 
held another workshop addressing topics such as the environment, climate change, and social engagement. Other events included the textiles campaign, the political nature meeting, and the exhibition, which was on display for six months and took place in the context of ecologically engaged art. In the summer, the educational film was presented to accompany the exhibition, which aimed to make viewers appreciate green areas and leave them unused, i.e., stop mowing. The exhibition also presented the achievements of various activist groups working in defence of nature. An interesting project was also the running of a helpline for a month within the exhibition for people struggling with the emotional consequences of climate change. The helpline was an invitation to an individual and anonymous telephone conversation with an experienced therapist specialising in this field.

\subsection{Institution 12}

Since 2019, the institution has been accompanied by the idea of the heritage for climate, which stems from the conviction that it is important to be involved in the process of supporting mitigation and adaptation measures related to global warming. The implementation of Heritage for Climate's demands has taken the form of a two-pronged action plan. Firstly, the institution recognised that an effective way of shaping pro-environmental attitudes is by setting a good example, and so a "green decalogue" of institutions was created. Implementing changes in institutional behaviour is treated as a permanent, self-improving process. Secondly, using knowledge, passion, space, and resources, the unit planned a programme of educational, exhibition, and tourism events. Despite the change in conditions related to the COVID-19 pandemic and the limited possibilities to implement many of the plans, it did not modify the theme of pro-environmental events. Since 2020, the institution has been a member of the Climate Heritage Network. In 2020, the unit published another issue of the periodically published free annual magazine, which was entirely devoted to the idea of heritage for climate. The magazine opened with a text declaring the commitment of cultural institutions to climate care and inviting people to reflect on the problem of global warming.

All educational activities held in the institution's headquarters or online (regardless of the subject matter) were organised on the basis of reusable, recyclable items, and recyclable materials. In its offer of educational activities, the institution presented several pro-ecological topics, which drew attention to the diversity of the local natural heritage, the selection of methods of caring for its elements, and forms of protection. When creating the scenarios for the summer activities, the unit tried to sensitise children to those ecological processes in nature that can be influenced by humans. During the activities, children were asked in which places people settled and what they decided when it became too crowded for all the inhabitants. The participants also got to know the animals that live near the Poznan's river. The activities contributed to the knowledge of non-material heritage, and were an opportunity to improve teamwork skills and to exercise spatial imagination. From February to April 2019, a series of classes were held for seniors. The cycle focused on topics related to regional tourism in Poland, including ecotourism and event tourism. Topics related to nature and its values, ecology, and responsible tourism were nature tourism, ecotourism, and responsible tourism. During the winter holidays of 2020, participants in the half-day camp learned about the concept of an ecological corridor and the functions of rivers past and present. A climate workshop was also organised during the same period, and the common denominator for all meetings was to draw attention to the climate crisis and to initiate changes that will contribute to its reduction. The series consisted of four thematic meetings on biodiversity, zero waste, the role of trees in oxygen production and carbon sequestration, and global warming. In September and October 2020, as part of the meetings for teachers, the institution prepared an online workshop on nature education, consisting of a theoretical and practical part, in which the local natural heritage was visited with a camera. The training was aimed at preparing teachers for outdoor activities of a natural-geographical, architectural, artistic and physical nature.

The institution also undertook tourist projects. One of them was an ethnobotanical walk and workshop, which encouraged people to look at the co-existence of people and 
plants in the space of Poznan's Old Town. In addition, guided walks were organised, which traced the relationship between nature and man in terms of the existence of historical and contemporary Poznan by the rivers, and familiarised people with the topic of urban greenery in the centre of Poznan. In 2019, a temporary exhibition about the animals was organised, presenting urban fauna as an important component of heritage. The exhibition was accompanied by a leaflet promoting environmentally friendly behaviours that can be implemented to help animals living in the city. The leaflet focused on showing activities that everyone can get involved in (e.g., issues of proper bird feeding, leaving places where animals can take refuge). In the spring of 2020, the institution prepared a folder, which allows people to look at the city from the side of the river and green areas. The folder was prepared in a physical version-a free printed material available in the institution headquarters and tourist information points, and in a PDF version to download from the institution website.

The institution was also the initiator of dozens of events, carried out in the formula of animation for families with children, performances, workshops, walks, outdoor screenings of short films, or study meetings. As part of the Greater Poland Regional Operational Programme 2014-2020, the institution implemented the project on environmental education in riverside areas in Poznan which demonstrated such components as a riverside ecoeducation path, a river eco-education garden and an experimental heritage garden. The institution's staff have also presented topics related to the institution's environmental activities on a wider forum, for example during the 5th Central European Heritage Forum.

\section{Discussion}

Municipal cultural institutions are units whose mission is to serve the society. They try to act in accordance with the principles of sustainable development, and also exert a positive influence on pro-ecological behaviour and attitudes of the recipients of the cultural offer, which can be exemplified by the activities of the institutions of Poznan presented in this article. These institutions undertake many eco-initiatives, which very often fit into the discourse on the so-called "deep ecology" and address the sources of the existing environmental crisis. Grassroots practices of cultural institutions are primarily aimed at stimulating the "return to nature' of city dwellers. This is done by appropriately designing living spaces in accordance with the ideas of permaculture or ecological education. Some of the initiatives presented in the paper also concern grassroots activities for the protection of greenery in the city and communities gathering around community gardens. Finally, some eco-initiatives deal with the issue of tree protection-they were considered from the cultural, natural, and ecological aspects. In addition to initiatives aimed at the recipients of the offer of individual institutions, many institutions also pay attention to pro-environmental internal activities. Summarising all the issues raised in the survey and dividing them into three general groups, we can distinguish between internal institutional activities, the implementation of projects on environmental issues, and educational activities in the field of ecology (Table 1).

The goal in the 2030 Agenda for Sustainable Development under point 13.3 of the "Climate Action" section recommend to improve education; awareness-raising; and human and institutional capacity on climate change mitigation, adaptation, impact reduction, and early warning [51]. The examples of municipal cultural institutions listed in the results section show that, among their many activities, they are contributing to this goal. Their projects have repeatedly focused on increasing access to knowledge, and through the many workshops and practical activities they have organized, they have raised awareness for the bottom-up mitigation of climate change, which every individual should start doing themselves. 
Table 1. Eco-initiatives undertaken by cultural institutions in Poznan.

\begin{tabular}{cccc}
\hline Institution & Eco-Initiatives Undertaken & \\
\hline Number & $\begin{array}{c}\text { Internal } \\
\text { Institutional Actions }\end{array}$ & $\begin{array}{c}\text { Implementation of } \\
\text { Environmental Projects }\end{array}$ & $\begin{array}{c}\text { Ecological Education } \\
\text { Activities }\end{array}$ \\
\hline 1 & No & Yes & No \\
2 & Yes & No & No \\
3 & No & Yes & Yes \\
4 & Yes & Yes & Yes \\
5 & No & No & No \\
6 & Yes & No & No \\
7 & Yes & Yes & Yes \\
8 & Yes & Yes & Yes \\
9 & Yes & Yes & Yes \\
10 & Yes & Yes & Yes \\
11 & Yes & Yes & Yes \\
12 & Yes & &
\end{tabular}

An analysis of the literature on the subject (scholarly articles available in the Scopus and Web of Science databases) leads to the conclusion that although there has not been comprehensive research dedicated to all types of cultural institutions combined, there are research findings related to specific institutions that can be juxtaposed with the findings presented in this article. Loach, Rowley, and Griffiths [6], conducting research in museums and libraries in the UK, concluded that the concept of cultural sustainability should be more widely introduced and developed in cultural policy contexts, and be considered central rather than ancillary to other sustainability issues. In contrast, StylianouLambert et al. [7], studying museums in Cyprus, concluded that most entities—regardless of their legal personality - should be encouraged through cultural policies to develop new and diverse audiences, stimulate intercultural dialogue, and represent cultural diversity. Researchers studying museums in Romania, Pop et al. [8], noted that effectiveness and performance, openness to the public, and heritage exposure have a positive impact on cultural sustainability. Similar results were also found for museums in Italy [9]. Thus, adopting Friedman's [52] thesis that sustainability is the great challenge for many cultural institutions in the twenty-first century and that the institutions have to build new, more sustainable models than the ones that served in the previous century, it should be recognised that most of the institutions surveyed based in Poznan have taken up this challenge and implemented a number of desirable actions. Although only one institution, which focuses on the cultivation of historical memory about the region in the Greater Poland capital took part in the study - and therefore still faces many of the challenges described by researchers analysing museums in the UK, Cyprus, Romania and Italy-other institutions have, in the last two years, opened up significantly to environmental initiatives on a number of levels, similarly with the institution focused on reading, whose research results are consistent with those presented by Loach and colleagues [6].

Gaweł [53], undertaking research on corporate social responsibility in the context of museums as an example of cultural institutions, noted that it is important to include social issues and concern for the environment in the development strategies of cultural institutions. He looked at institutions from two sides-internally, focused on identity construction, and externally, focused on the environment-and the research conducted indicated that the improvement of the quality of the functioning of entities can be influenced by appealing to values. The results of Gawel's research [53] are in line with the results obtained in this study, as the Poznan institutions in the vast majority in the last two years implemented internal institutional actions, implemented projects with ecological themes, and undertook educational activities in the field of ecology. The results of the research also confirm the tendency noticed by Ścibiorska-Kowalczyk et al. [54] in the study of the cultural levels of South Korea, that society is becoming more and more focused on the mass consumption of cultural goods related to the subject of sustainable development, as evidenced by the 
number of pro-ecological initiatives implemented in the capital of Greater Poland. The responses of the directors (or their representatives) of the institution did not, however, confirm the research conducted by Murzyn-Kupisz [55], who pointed out that from the point of view of sustainable development, the most successful projects are those related to culture and cultural heritage, which are created and implemented with the cooperation of many key local actors - the cultural institutions in Poznan do not undertake large-scale activities in cooperation with other institutions, nor did the conducted interviews confirm the dominant role of local actors in the implemented environmental initiatives. Although all the institutions are characterised by the extremely close location of their seats in the very centre of the city, this has not contributed to any activities integrating the scenes, as the institutions act individually, not undertaking any joint undertakings with regard to the exhibited works.

The research we conducted has its limitations. Because the research was conducted during the COVID-19 pandemic, and the difficulty of holding face-to-face meetings, both the request for responses and the process of obtaining them were carried out remotely through email or telephone calls. Although we made every effort to have all directors (or their representatives) of the municipal cultural institutions in Poznan respond to us, unfortunately the managing representatives of three municipal cultural institutions did not respond to our request, which meant that we obtained data from $80 \%$, rather than $100 \%$, of all municipal cultural institutions. Moreover, we have no information about in what conditions (resulting, for example, from the place of filling in or access to the internet) the answers were given. In the case of constructing longer written answers, barriers may also have resulted from answering intermittently (between other management duties), for technical reasons, or even because of different skills in formulating answers or presenting different approaches to the topic of ecology.

\section{Conclusions}

In recent years, there has been a concern for the state of the environment, so it is becoming an important objective to shape an appropriate attitude of society towards the environment, as well as the need to solve many problems occurring both in the economic and social sphere. The picture of Poznan's cultural institutions presented in this article shows that the eco-initiatives undertaken are beneficial—as evidenced by the great interest of the public in such undertakings. These activities can also serve as inspiration for others. This is because cultural institutions rely on the development of good practices and may, through their activity, contribute to the formation of attitudes of greater openness to the environment. The existing eco-trend makes it possible to believe that as the years go by, society will become increasingly aware of the nature of pro-environmental activities undertaken. The education of the youngest-children or youth-may not only shape in them appropriate behaviour in the scope of caring for the environment, but it may also translate into increased ecological awareness in their families or among older generations who, wanting to set a good example for the younger ones, will also change their current attitudes, which often have little in common with ecology. Although environmental responsibility is part of a broad philosophy of the functioning of a modern economy, one should also bear in mind the potential issues that may stand in the way of the implementation of such a policy. One of them may be the relatively high cost of eco-initiatives and living in a zero-waste style, which is already appearing in research discussions [56,57]. The recent increase in inflation in Poland makes saving money important for people living in Polish cities, for example in Poznan, who may be unhappy with the policy of spending more on environmental activities and feel that public money is being misspent. Both city authorities and managers of institutions-including cultural institutions-must therefore be prepared for such reactions.

The obtained results leave room for further research challenges-an interesting perspective may be the examination of the role of management bodies, staff, communities, and other external bodies in sustaining the cultural value of individual organisations. The 
analysis of any kind of conflict that may exist between the cultural missions of organisations and the broader goals of sustainable development also seems to be an important and, as yet, not fully explored issue. It is also worth extending the study of cultural institutions from the point of view of marketing management [58], or the offer for people buying souvenirs, increasingly produced organically, at cultural institutions-if, of course, the units in question have gadget shops on offer [59].

Author Contributions: Conceptualization, M.R.; methodology, M.R. and E.M.-M.; software, M.R.; validation, M.R.; formal analysis, M.R.; investigation, M.R.; resources, M.R., K.N., E.M.-M. and Z.D.-P.; data curation, M.R.; writing—original draft preparation, M.R. and Z.D.-P.; writing-review and editing, M.R., K.N., E.M.-M. and Z.D.-P.; visualization, M.R.; supervision, M.R.; project administration, M.R; funding acquisition, K.N. and Z.D.-P. All authors have read and agreed to the published version of the manuscript.

Funding: The project is funded under the program of the Minister of Science and Higher Education titled "Regional Initiative of Excellence" in 2019-2022, project number 018/RID/2018/19, the amount of funding PLN 10788 423,16.

Institutional Review Board Statement: Not applicable.

Informed Consent Statement: The study was treated according to the guidelines in the Publication Manual of the American Psychological Association. The subjects gave their informed consent to participate in the study.

Data Availability Statement: Not applicable.

Conflicts of Interest: The authors declare no conflict of interest.

\section{References}

1. Sakaeva, R.L.; Sabirova, D.R.; Yahin, M.A.; Kuznetsova, E.V. Culture and civilization: Functional and methodological aspects. Rev. Publicando 2018, 16, 435-442.

2. Żak, K. Implementing Sustainable Development through the Prism of Social Inclusion as Illustrated by the Castle Museum in Pszczyna. Cult. Manag. Sci. Educ. 2020, 4, 3957. [CrossRef]

3. Kuznetsova, R.V.; Goryacheva, O.N.; Patenko, G.R. Phenomenon of Mass Culture: Problems and Contradictions. Mediterr. J. Soc. Sci. 2015, 3, 296-301. [CrossRef]

4. Wróblewski, Ł.; Gaio, A.; Rosewall, E. Sustainable Cultural Management in the 21st Century. Sustainability 2019, $11,4665$. [CrossRef]

5. Agenda 21 for Culture; Ajuntament de Barcelona, United Cities and Local Governments-Committee on Culture: Barcelona, Spain, 2008.

6. Loach, K.; Rowley, J.; Griffiths, J. Cultural sustainability as a strategy for the survival of museums and libraries. Int. J. Cult. Pol. 2017, 2, 186-198. [CrossRef]

7. Stylianou-Lambert, T.; Boukas, N.; Christodoulou-Yerali, M. Museums and cultural sustainability: Stakeholders, forces, and cultural policies. Int. J. Cult. Pol. 2014, 5, 566-587. [CrossRef]

8. Pop, I.L.; Borza, A.; Buiga, A.; Ighian, D.; Toader, R. Achieving Cultural Sustainability in Museums: A Step toward Sustainable Development. Sustainability 2019, 11, 970. [CrossRef]

9. Errichiello, L.; Micera, R. Leveraging Smart Open Innovation for Achieving Cultural Sustainability: Learning from a New City Museum Project. Sustainability 2018, 10, 1964. [CrossRef]

10. Wróblewski, Ł.; Dacko-Pikiewicz, Z. Sustainable Consumer Behaviour in the Market of Cultural Services in Central European Countries: The Example of Poland. Sustainability 2018, 10, 3856. [CrossRef]

11. Stverkova, H.; Pohludka, M.; Kurowska-Pysz, J.; Szczepańska-Woszczyna, K. Cross-border enterpreneurship in Euroregion Beskydy. Pol. J. Manag. Stud. 2018, 2, 324-337. [CrossRef]

12. Klarin, T. The Concept of Sustainable Development: From its Beginning to the Contemporary Issues. Zagreb Int. Rev. Econ. Bus. 2018, 21, 67-94. [CrossRef]

13. Shi, L.; Han, L.; Yang, F.; Gao, L. The Evolution of Sustainable Development Theory: Types, Goals, and Research Prospects. Sustainability 2019, 11, 7158. [CrossRef]

14. Pyke, G.H. Sustainability for Humanity: It's Time to Preach beyond the Converted. Trends Ecol. Evol. 2017, 6, 391-394. [CrossRef]

15. Ustawa z dnia 25 Października 1991 r. o Organizowaniu i Prowadzeniu Działalności Kulturalnej. Dz.U., 1991, nr 114, poz. 493 [Act of 25 October 1991 on Organising and Conducting Cultural Activity. Law Gazette, 1991, No. 114, Item 493], Poland. Available online: https:/ / isap.sejm.gov.pl/isap.nsf/DocDetails.xsp?id=WDU19911140493 (accessed on 29 December 2021).

16. Jagodzińska, K. Charakterystyka działalności kulturalnej w Polsce po transformacji. In Kultura a Rozwój; Hausner, J., Karwańska, A., Purchla, J., Eds.; Narodowe Centrum Kultury: Warsaw, Poland, 2013; pp. 127-159. 
17. Wróblewski, Ł. Strategie Marketingowe w Instytucjach Kultury; PWE: Warsaw, Poland, 2012.

18. Wróblewski, Ł.; Dziadzia, B.; Dacko-Pikiewicz, Z. Sustainable Management of the Offer of Cultural Institutions in the Cross-Border Market for Cultural Services-Barriers and Conditions. Sustainability 2018, 10, 3253. [CrossRef]

19. Broman, G.I.; Robert, K.-H. A framework for strategic sustainable development. J. Clean. Prod. 2017, 140, 17-31. [CrossRef]

20. Soini, K.; Birkeland, I. Exploring the scientific discourse on cultural sustainability. Geoforum 2014, 51, 213-223. [CrossRef]

21. Paul, J.; Magee, L.; Scerri, A.; Steger, M.B. Urban Sustainability in Theory and Practice: Circles of Sustainability; Routledge: London, UK, 2015.

22. Bender, O.; Haller, A. The cultural embeddedness of population mobility in the Alps: Consequences for sustainable development. Nor. Geogr. Tidsskr.-Nor. J. Geogr. 2017, 3, 132-145. [CrossRef]

23. Pascual, J. Cultural Policies, Human Development and Institutional Innovation: Or Why We Need an Agenda 21 for Culture. In Proceedings of the Exapnding Cultures, Arts and Local Government Conference, Chapel off Chapel, Prahran, Victoria, Australia, 24-27 July 2007.

24. The World in 2050. In Transformations to Achieve the Sustainable Development Goals; International Institute for Applied Systems Analysis: Laxenburg, Austria, 2018.

25. Butler, R. Tourism, Environment, and Sustainable Development. Environ. Conservat. 1991, 3, 201-209. [CrossRef]

26. Baros, Z.; Dávid, L. Environmentalism and sustainable development from the point of view of tourism. Tour. Int. Multidiscip. J. Tour. 2007, 2, 141-152. [CrossRef]

27. Trendafilova, S.; McCullough, B.P.; Pfahl, M.; Nguyen, S.N.; Casper, J.M.; Picariello, M. Environmental sustainability in sport: Current state and future trends. Glob. J. Adv. Pure Appl. Sci. 2014, 3, 9-14.

28. McCullough, B.; Pfahl, M.; Nguyen, S.N. The green waves of environmental sustainability in sport. Sport Soc. $2016,7,1040-1065$. [CrossRef]

29. Thormann, T.F.; Wicker, P. Willingness-to-Pay for Environmental Measures in Non-Profit Sport Clubs. Sustainability 2021, 13, 2841. [CrossRef]

30. Poczta, J.; Almeida, N.; Rozmiarek, M.; Młodzik, M.; Malchrowicz-Mośko, E. Men’s and Women’s Style of Living and Motivation to Run in Charity Events. Sustainability 2021, 13, 5287. [CrossRef]

31. Dickson, T.; Darcy, S.; Walker, C. A Case of Leveraging a Mega-Sport Event for a Sport Participation and Sport Tourism Legacy: A Prospective Longitudinal Case Study of Whistler Adaptive Sports. Sustainability 2021, 13, 170. [CrossRef]

32. Cohen, B. Sustainable valley entrepreneurial ecosystems. Bus. Strat. Environ. 2006, 1, 1-14. [CrossRef]

33. Van de Ven, A.H. The development of an infrastructure for entrepreneurship. J. Bus. Ventur. 1993, 8, 211-230. [CrossRef]

34. Spilling, O.R. The entrepreneurial system: On entrepreneurship in the context of a mega-event. J. Bus. Res. 1996, 1,91-103. [CrossRef]

35. Shapero, A.; Sokol, L. The Social Dimensions of Entrepreneurship, in Encyclopedia of Entrepreneurship. In University of Illinois at Urbana-Champaign's Academy for Entrepreneurial Leadership Historical Research Reference in Entrepreneurship; Kent, C.A., Sexton, D.L., Vesper, K.H., Eds.; Prentice-Hall: Englewood Cliffs, NJ, USA, 1982; pp. 72-98.

36. Florida, R.; Kenney, M. Venture capital and high-technology entrepreneurship. J. Bus. Ventur. 1988, 4, 301-319. [CrossRef]

37. Neck, H.; Meyer, D.; Cohen, B.; Corbett, A. An Entrepreneurial System View of New Venture Creation. J. Small Bus. Manag. 2004, 2, 190-208. [CrossRef]

38. Laumann, E.O.; Galaskiewicz, L.; Marsden, P.V. Community Structure as Interorganizational Linkages. Annu. Rev. Sociol. 1978, 4, 455-484. [CrossRef]

39. Mintzberg, H.; Ahlstrand, B.; Lampel, J. Strategy Safari: A Guided Tour through the Wilds of Strategic Management; Free Press: New York, NY, USA, 1998.

40. Lewandowski, M. Sprawność zarządzania instytucjami kultury. In Efektywność Zarządzania Organizacjami Publicznymi i Jej Pomiar; Frączkiewicz-Wronka, A., Ed.; University of Economics: Katowice, Poland, 2013; pp. 139-151.

41. Markiel, K. Syndrom odpowiedzialności. Optyka samorządowa-Małopolska. In Ogólnopolski Kongres: Kultura-Gospodarka-Media; Orzechowski, E., Ed.; Centrum Animacji Kultury: Krakow, Poland, 2002; pp. 31-52.

42. Jach, A. Ekologia Instytucji-Warsztaty Pilotażowe [Ecology of Institutions-Pilot Workshops]. Available online: http: / / theanthropoceneindex.com/article/47-Ekologia-instytucji-warsztaty-pilotazowe (accessed on 2 January 2022).

43. Murzyn-Kupisz, M.; Działek, J. Rola instytucji kultury w budowaniu i wzmacnianiu kapitału społecznego jako czynnika rozwoju społeczno-gospodarczego. In Sektor Kreatywny Jako Katalizator Przemian Strukturalnych w Regionie; Klasik, A., Ed.; University of Economics: Katowice, Poland, 2014; pp. 191-217.

44. Modzelewska, A.; Skuza, S.; Szeluga-Romańska, M.; Materska-Samek, M. Towards Greater Citizen Participation in Financing Public Cultural Institutions-Legal Barriers and Proposed Solutions. Sustainability 2020, 12, 7957. [CrossRef]

45. Designation of the European Capital of Culture 2016. Selection Panel; Report on Pre-Selection: Warsaw, Poland, 2010.

46. Hawkes, J. The Fourth Pillar of Sustainability. Culture's Essential Role in Public Planning; Common Ground P/L: Melbourne, VIC, Australia, 2001.

47. UNESCO. Placing Culture at the Heart of Sustainable Development Policies; UNESCO: Paris, France, 2013.

48. Apanowicz, J. Metodologia Ogólna; Bernardinum: Gdynia, Poland, 2002.

49. American Psychological Association. Publication Manual of the American Psychological Association; American Psychological Association: Washington, DC, USA, 2020. 
50. Malchrowicz-Mośko, E.; Botiková, Z.; Poczta, J. “Because We Don't Want to Run in Smog”: Problems with the Sustainable Management of Sport Event Tourism in Protected Areas (A Case Study of National Parks in Poland and Slovakia). Sustainability 2019, 11, 325. [CrossRef]

51. United Nations. Resolution Adopted by the General Assembly on 6 July 2017, Work of the Statistical Commission Pertaining to the 2030 Agenda for Sustainable Development (A/RES/71/313), United States. Available online: https://ggim.un.org/ documents/a_res_71_313.pdf (accessed on 6 January 2022).

52. Friedman, A.J. The Great Sustainability Challenge: How Visitor Studies Can Save Cultural Institutions in the 21st Century. Visit. Stud. 2007, 1, 3-12. [CrossRef]

53. Gaweł, Ł. Zarządzanie publicznymi instytucjami kultury w kontekście koncepcji corporate social responsibility (CSR). Społeczna odpowiedzialność muzeum. Stud. Ekon. 2018, 376, 48-62.

54. Ścibiorska-Kowalczyk, I.; Cichoń, J. The Significance of Cultural Policy-Case Study of South Korea. Sustainability 2021, 13, 13805. [CrossRef]

55. Murzyn-Kupisz, M. Kultura i dziedzictwo kulturowe a rozwój zrównoważony. Stud. KPZK 2013, 152, 92-105.

56. Bogusz, M.; Matysik-Pejas, R.; Krasnodębski, A.; Dziekański, P. The Concept of Zero Waste in the Context of Supporting Environmental Protection by Consumers. Energies 2021, 14, 5964. [CrossRef]

57. Hannon, J.; Zaman, A.U. Exploring the Phenomenon of Zero Waste and Future Cities. Urban Sci. 2018, 2, 90. [CrossRef]

58. Gilmore, A.; Rentschler, R. Changes in museum management: A custodial or marketing emphasis? J. Manag. Dev. 2002, 10, 745-760. [CrossRef]

59. Li, Z.; Shu, S.; Shao, J.; Booth, E.; Morrison, A.M. Innovative or Not? The Effects of Consumer Perceived Value on Purchase Intentions for the Palace Museum's Cultural and Creative Products. Sustainability 2021, 13, 2412. [CrossRef] 